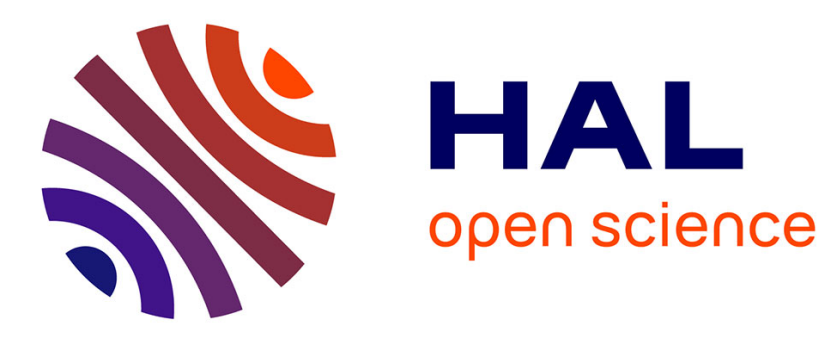

\title{
Market efficiency in the European carbon markets
} Amélie Charles, Olivier Darné, Jessica Fouilloux

\section{To cite this version:}

Amélie Charles, Olivier Darné, Jessica Fouilloux. Market efficiency in the European carbon markets. Energy Policy, 2013, 60, pp.785-792. 10.1016/j.enpol.2013.05.036 . halshs-00846679

\section{HAL Id: halshs-00846679 \\ https://shs.hal.science/halshs-00846679}

Submitted on 30 Apr 2015

HAL is a multi-disciplinary open access archive for the deposit and dissemination of scientific research documents, whether they are published or not. The documents may come from teaching and research institutions in France or abroad, or from public or private research centers.
L'archive ouverte pluridisciplinaire HAL, est destinée au dépôt et à la diffusion de documents scientifiques de niveau recherche, publiés ou non, émanant des établissements d'enseignement et de recherche français ou étrangers, des laboratoires publics ou privés. 


\title{
Market Efficiency in the European Carbon Markets
}

\author{
Amélie CHARLES* \\ Audencia Nantes, School of Management
}

Olivier DARNÉ ${ }^{\dagger}$

LEMNA, University of Nantes

Jessica FOUILLOUX

CREM, University of Rennes 1

${ }^{*}$ Audencia Nantes, School of Management, 8 route de la JoneliÃíre, 44312 Nantes, France. Email: acharles@audencia.com.

†Corresponding author: LEMNA, University of Nantes, IEMN-IAE, Chemin de la Censive du Tertre, BP 52231, 44322 Nantes, France. Tel: +33 (0)2 401417 33. Fax: +33 (0)2 40141650 . Email: olivier.darne@univ-nantes.fr.

†University of Rennes 1, 11 rue Jean MacÃl’, CS 70803, 35708 Rennes Cedex 7, France. Email: jessica.fouilloux@univ-rennes1.fr. 


\begin{abstract}
In this paper, we study the relationship between futures and spot prices in the European carbon markets from the cost-of-carry hypothesis. The aim is to investigate the extent of efficiency market. The three main European markets (BlueNext, EEX and ECX) are analyzed during Phase II, covering the period from March 13, 2009 to January, 17, 2012. Futures contracts are found to be cointegrated with spot prices and interest rates for several maturities in the three $\mathrm{CO}_{2}$ markets. Results are similar when structural breaks are taken into account. According to individual and joint tests, the cost-of-carry model is rejected for all maturities and $\mathrm{CO}_{2}$ markets, implying that neither contract is priced according to the cost-of-carry model. The absence of the cost-of-carry relationship can be interpreted as an indicator of market inefficiency and may bring arbitrage opportunities in the $\mathrm{CO}_{2}$ market.
\end{abstract}

Keywords: $\mathrm{CO}_{2}$ emission allowances; Cost-of-carry model; Spot and futures prices; Market efficiency.

JEL Classification: G13; G14; Q50; C32. 


\title{
Market Efficiency in the European Carbon Markets
}

\begin{abstract}
In this paper, we study the relationship between futures and spot prices in the European carbon markets from the cost-of-carry hypothesis. The aim is to investigate the extent of efficiency market. The three main European markets (BlueNext, EEX and ECX) are analyzed during Phase II, covering the period from March 13, 2009 to January, 17, 2012. Futures contracts are found to be cointegrated with spot prices and interest rates for several maturities in the three $\mathrm{CO}_{2}$ markets. Results are similar when structural breaks are taken into account. According to individual and joint tests, the cost-of-carry model is rejected for all maturities and $\mathrm{CO}_{2}$ markets, implying that neither contract is priced according to the cost-of-carry model. The absence of the cost-of-carry relationship can be interpreted as an indicator of market inefficiency and may bring arbitrage opportunities in the $\mathrm{CO}_{2}$ market.
\end{abstract}

Keywords: $\mathrm{CO}_{2}$ emission allowances; Cost-of-carry model; Spot and futures prices; Market efficiency.

JEL Classification: G13; G14; Q50; C32. 


\section{Introduction}

The European Union Emission Trading Scheme (EU ETS) went into effect on January 2005, considering the EU Directive 2003/87/EC. The EU ETS is one of the most important initiatives taken to reduce the greenhouse gas (GHG) emissions (primarily $\mathrm{CO}_{2}$ ) that cause climate change (Kyoto protocol). The inclusion of the aviation sector from January $1^{\text {st }} 2012$ onwards represents a new step in the implementation of the EU ETS..$^{1}$ Following the steady expansion of the EU ETS' scope to new Member States since 2005, the European Commission is now adding around 5,000 European airline companies and foreign companies that do business in Europe to the 11500 industrial and manufacturing participating installations. In 2010, it is estimated that the sources to which the trading scheme applies account for 45 per cent of $\mathrm{CO}_{2}$ emissions and a little less than 40 per cent of total GHG emissions in that year.

The EU ETS introduces a cap-and-trade system, which operates through the creation and distribution of tradable rights to emit, usually called EU allowances $(\text { EUAs })^{2}$ to installations. Since a constraining cap creates a scarcity rent, these EUAs have value. The distribution of these rights for free is called free allocation and is the unique feature of this cap-and-trade system. The cap-and-trade scheme operates over discrete periods, with the first or pilot period (Phase I, 2005-2007) and with the second period corresponding to the first commitment period of the Kyoto Protocol. This period extends from 2008 to 2012 (Phase II) and will be followed by a third period from

\footnotetext{
${ }^{1}$ To improve the fluidity of the EU ETS, organized allowance trading has been segmented across trading platforms: Nordic Power Exchange (Nord Pool) in Norway began in February 2005, European Energy Exchange (EEX) in Germany began in March 2005, European Climate Exchange (ECX) based in London and Amsterdam started in April 2005, BlueNext in France and Energy Exchange Austria (EEA) in Austria began in June 2005, and SendeCO2 in Spain started at the end of 2005.

${ }^{2}$ In fact, the EUAs are the conversion of Assigned Amount Units (AAUs), which are the permits allocated to Annex B of the Kyoto Protocol. See Convery (2009) and Chevallier (2012) for a discussion of the EU ETS.
} 
2013 to 2020 (Phase III). Phase II represents the fundamental regulatory tool allowing Member States to reach their Kyoto target. The EU target is a reduction of 8 per cent below 1990 emissions in the 2008-2012 period ${ }^{3}$ To help countries in achieving their reduction objectives, the Protocol includes three flexibility mechanisms: The creation of an International Emission Trading, Joint Implementation and the Clean Development Mechanism 4

The EU ETS includes spot, futures, and option markets with a total market value of $€ 72$ billion in 2010. Futures contracts account for a wide part of this value (about $87 \%$ in 2010). Understanding the relationship between spot and futures prices is thus of crucial importance for all participants in the carbon market. Carbon trading works only if markets for carbon provide enough liquidity and pricing accuracy, i.e., markets provide prices that are useful for hedgers and other users of carbon markets. The efficiency of the $\mathrm{CO}_{2}$ market is particularly important for emission intensive firms, policy makers, risk managers and for investors in the emerging class of energy and carbon hedge funds (see Krishnamurti and Hoque, 2011).

Although relevant papers have been published on the behavior of emission allowance spot and futures prices (see, e.g., Alberola et al., 2008; Daskalakis and

\footnotetext{
${ }^{3}$ Phase III is set to help meet the European target of 20 per cent GHG emission reduction in 2020 compared to 1990, in line with the objective of the Climate Energy Package approved in December 2008.

${ }^{4}$ The Joint Implementation (JI) mechanism consists of the realization of an emission reduction project by a developed country (Annex I country) in another developed country (Annex I). JI projects provide for Emission Reduction Units (ERUs) that may be utilized by an Annex I country promoting the project to meet its emission targets under the Kyoto Protocol. The Clean Development Mechanism (CDM) provides for a similar mechanism for an Annex I country to achieve its emissions target when the project is implemented in a developing country. The units arising from such projects are termed Certified Emission Reduction units (CERs). In 2011, the volume of transactions amounted to 6,053 million EUAs, 1,418 million CERs and 62.8 million ERUs (up 20\%, 53\% and 1,406\%, respectively, compared with 2010).
} 
Markellos, 2008; Paolella and Taschini, 2008; Seifert et al., 2008; Benz and Trück, 2009), studies on $\mathrm{CO}_{2}$ market efficiency between futures and spot prices are rather sparse (Daskalakis et al., 2009; Uhrig-Homburg and Wagner, 2009; Joyeux and Milunovich, 2010). These studies examine the extent of market efficiency in the $\mathrm{CO}_{2}$ futures market by conducting empirical tests of the cost-of-carry model, which allow to ascertain the degree to which carbon futures prices reflect their theoretical (no arbitrage) values. This approach is especially useful in the context of examining whether futures contracts are efficiently priced with respect to the underlying emission rights allowances. If these contracts are efficiently priced then participating countries and covered installations in them can achieve environmental compliance in a costeffective and optimal manner (Krishnamurti and Hoque, 2011).

The aim of this paper is to investigate the efficiency hypothesis between spot and futures prices negotiated on European markets from a cost-of-carry model, by extending the previous studies in three ways: (i) we study the three main European markets, BlueNext, European Energy Exchange (EEX), and European Climate Exchange (ECX); (ii) we consider the second trading period (Phase II) from March 13, 2009 to January, 17, 2012; and (iii) we test the cost-of-carry model using four futures contracts (December 2009, December 2010, December 2011 and December 2012 maturities). This study should give a more complete picture of the relationships between spot and futures prices in the EU ETS. We apply the cointegration methodology developed by Johansen $(1988,1991)$ to test for multivariate cointegration between the series (futures prices, spot prices and interest rate) before estimating the cost-of-carry relationship. Indeed, the theoretical connection between spot and futures prices is a long-run, rather than short-run, concept. In the shortrun, there might be deviations between spot prices and futures prices, that can be induced by, for example, thin trading or lags in information transmission (Maslyuk and Smyth, 2009). The visual inspection of the data in Figures 1-3 reveals a sharp 
price break for spot and futures price series of all maturities in the three markets in June 2011. This fall of $20 \%$ followed the announcement of a Directive of the European Commission for cutting energy consumption in buildings, vehicles and more controversially, industry 5 Therefore, we also use the approach suggested by Johansen et al. (2000) to take into account the presence of structural breaks. ${ }^{6}$

The remainder of this paper is organized as follows: Section 2 presents the cost-ofcarry model. A brief literature review is given in Section 3. Section 4 displays the cointegration tests with and without structural breaks. The empirical framework is discussed in Section 5. The conclusion is drawn in Section 6.

Figure 1: Daily spot and futures prices for BlueNext

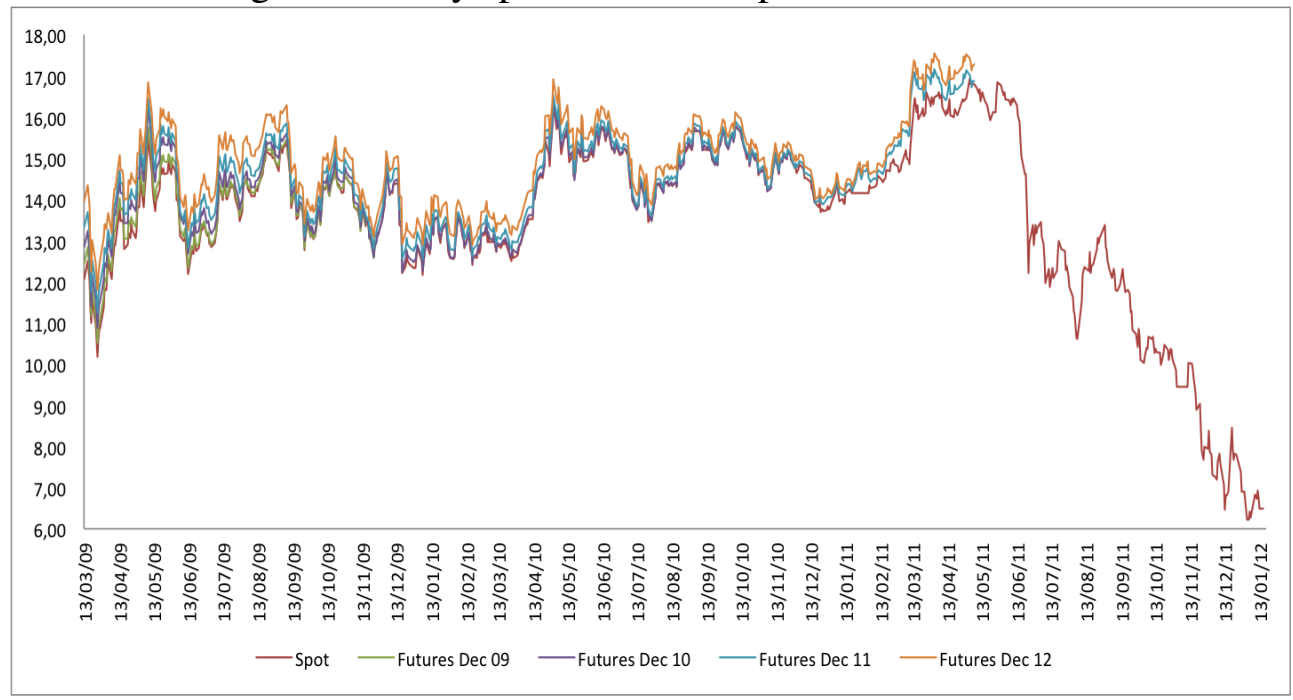

\footnotetext{
${ }^{5}$ We use in Section 5 the approach of Bai and Perron (2003) to identify the (possible) presence of structural breaks in the spot and futures EUA prices.

${ }^{6}$ Gregory et al. (1996) show that the rejection frequency of cointegration tests of the null hypothesis of no cointegration is considerably reduced in the presence of structural breaks. As a consequence, the null hypothesis may be (incorrectly) not rejected due to the existence of a break.
} 
Figure 2: Daily spot and futures prices for EEX

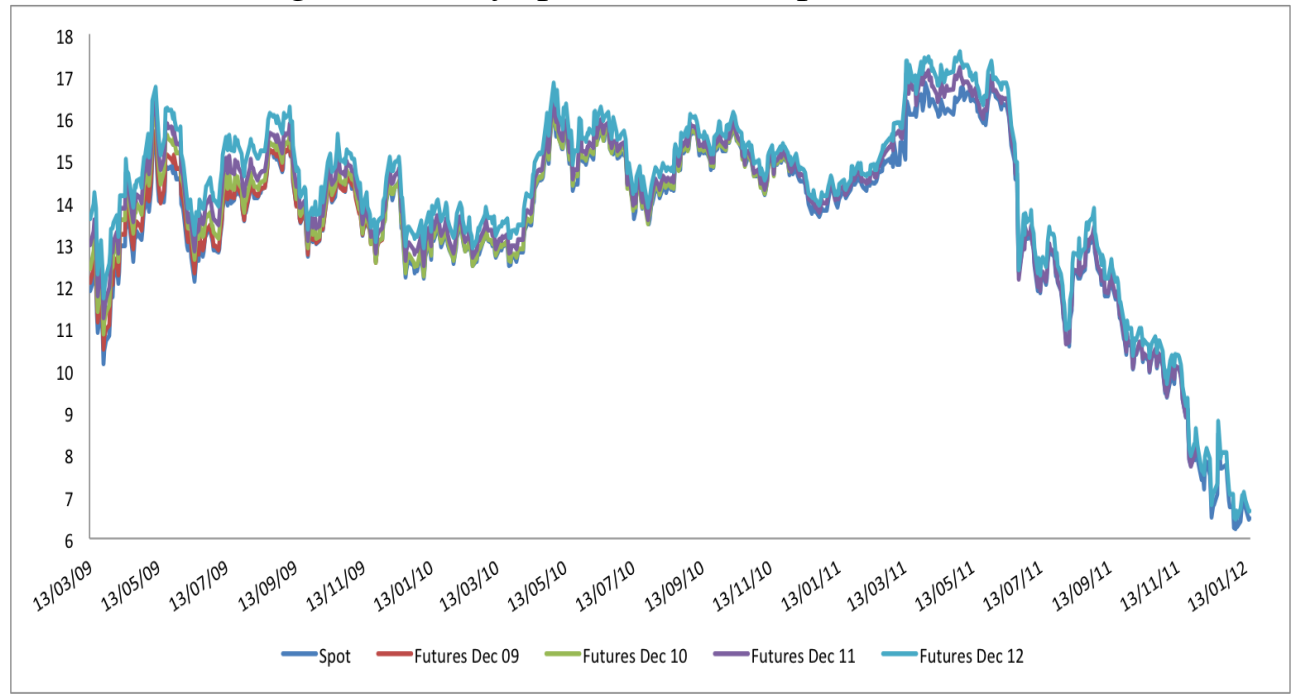

Figure 3: Daily spot and futures prices for ECX

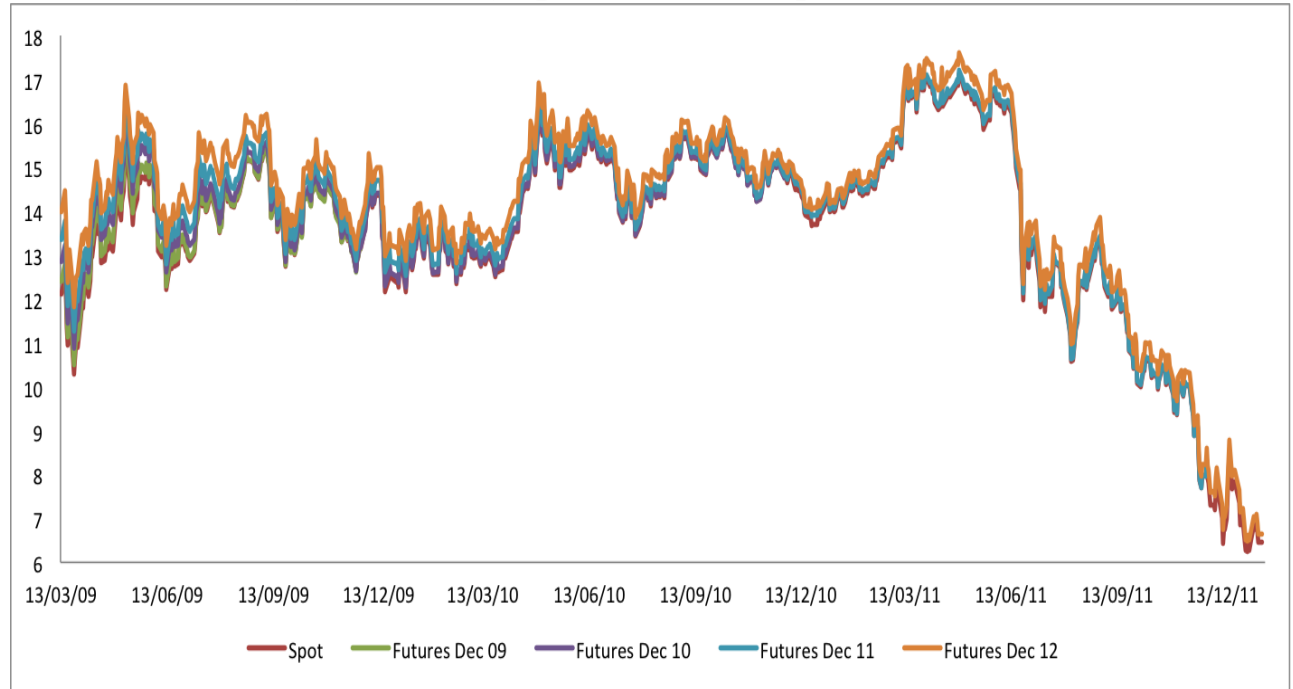

\section{The cost-of-carry model}

Theoretically, if spot and futures markets operate efficiently and are frictionless, futures contracts should be traded at a price known as the fair value (the Law of One 
Price). The starting point of most studies is the arbitrage free or cost-of-carry model in which the futures price is represented as

$$
F_{t}=S_{t} e^{(r+u-y)(T-t)}
$$

where $F_{t}$ is the futures price at time $t ; S_{t}$ is the spot price at time $t ; r$ is the risk-free interest rate; $u$ is the storage cost ; $y$ is either a dividend yield in the case of a dividend paying stock or a convenience yield in the case of commodity; and $T$ is the expiration date of the futures contract, and $(T-t)$ is the time to expiry of the futures contract.

The storage costs for $\mathrm{CO}_{2}$ allowances are nil because they only exist on a companies' balance sheet. Taking logarithms of both sides of Equation (1) gives

$$
\operatorname{Ln}\left(F_{t}\right)=\operatorname{Ln}\left(S_{t}\right)+(r-y)(T-t)
$$

Various approaches are possible to determine term structure by using alternative model specifications for the convenience yield term. Nevertheless, there is no consensus about the state of futures prices (backwardation, normal backwardation, contango and normal contango) $!^{7}$ The different possible states of the $\mathrm{CO}_{2}$ emissions market for each maturity is given in Table 1. As in Borak et al. (2006), the futures of the three markets appear to be in contango, whatever the maturity. Considering Kaldor (1939), the convenience yield appears as a way to explain backwardation, a situation where the

\footnotetext{
${ }^{7}$ The futures market is said to exhibit backwardation when the futures price $F_{t, T}$ is less or equal the current spot price $S_{t}$, it exhibits normal backwardation when the futures price is less or equal the expected spot price $E_{t}\left(S_{T}\right)$ in $T$. On the other hand the term (normal) contango is used to describe the opposite situation, when the futures price $F_{t, T}$ exceeds the (expected) spot price in $T$ (Borak et al., 2006). In others words, backwardation and contango are used to describe the relationship between current spot prices and futures prices whereas normal backwardation and normal contango are used for the relationship between expected spot prices and futures price. The idea of normal backwardation and normal contango was initially suggested by Keynes (1930) and Hicks (1946).
} 
futures price is lower than the spot price. Consequently, in this paper we will consider a cost and carry model with zero convenience yield

$$
\operatorname{Ln}\left(F_{t}\right)=\operatorname{Ln}\left(S_{t}\right)+r(T-t)
$$

This equation suggests a long-term relationship between the series.$^{8}$ The term $(T-t)$ in the brackets represents a reverse time trend that starts at $T$ years to contract maturity, and ends at zero as $t$ approaches $T$.

In order to test the cost-of-carry model empirically, we re-specify Equation (3) as

$$
\operatorname{Ln}\left(F_{t}\right)=\alpha \operatorname{Ln}\left(S_{t}\right)+\beta r(T-t)+\varepsilon_{t}
$$

where $\varepsilon_{t}$ is a white noise error term. Simple empirical tests of the efficiency hypothesis are based on the following single and joint hypothesis tests: $\mathrm{H}_{0}: \alpha=1, \mathrm{H}_{0}: \beta=1$, and

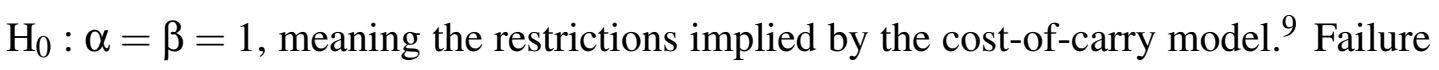
to reject the joint hypothesis implies that the cost-of-carry hypothesis is not rejected, suggesting an efficiency of the market. In a perfectly efficient and frictionless market, the pricing relationship expressed in Equation (2) should hold at every instant over a futures contract life (Stoll and Whaley, 1990). However, as underlined by Joyeux and Milunovich (2010), in the presence of market frictions, such as transaction costs and order execution lags, the no-arbitrage condition should hold in the long run but not necessarily in the short term.

\section{Brief literature survey}

Few studies examine the extent of market efficiency in the $\mathrm{CO}_{2}$ futures market by conducting empirical tests of the cost-of-carry model, which allow to ascertain the degree to which carbon futures prices reflect their theoretical (no arbitrage) values.

\footnotetext{
${ }^{8}$ Asymptotic inference concerning just identified cointegrating vectors can be conducted as if they were Gaussian, provided parameters are estimated by the maximum likelihood procedure.

${ }^{9}$ The joint test is more powerful than the individual tests.
} 


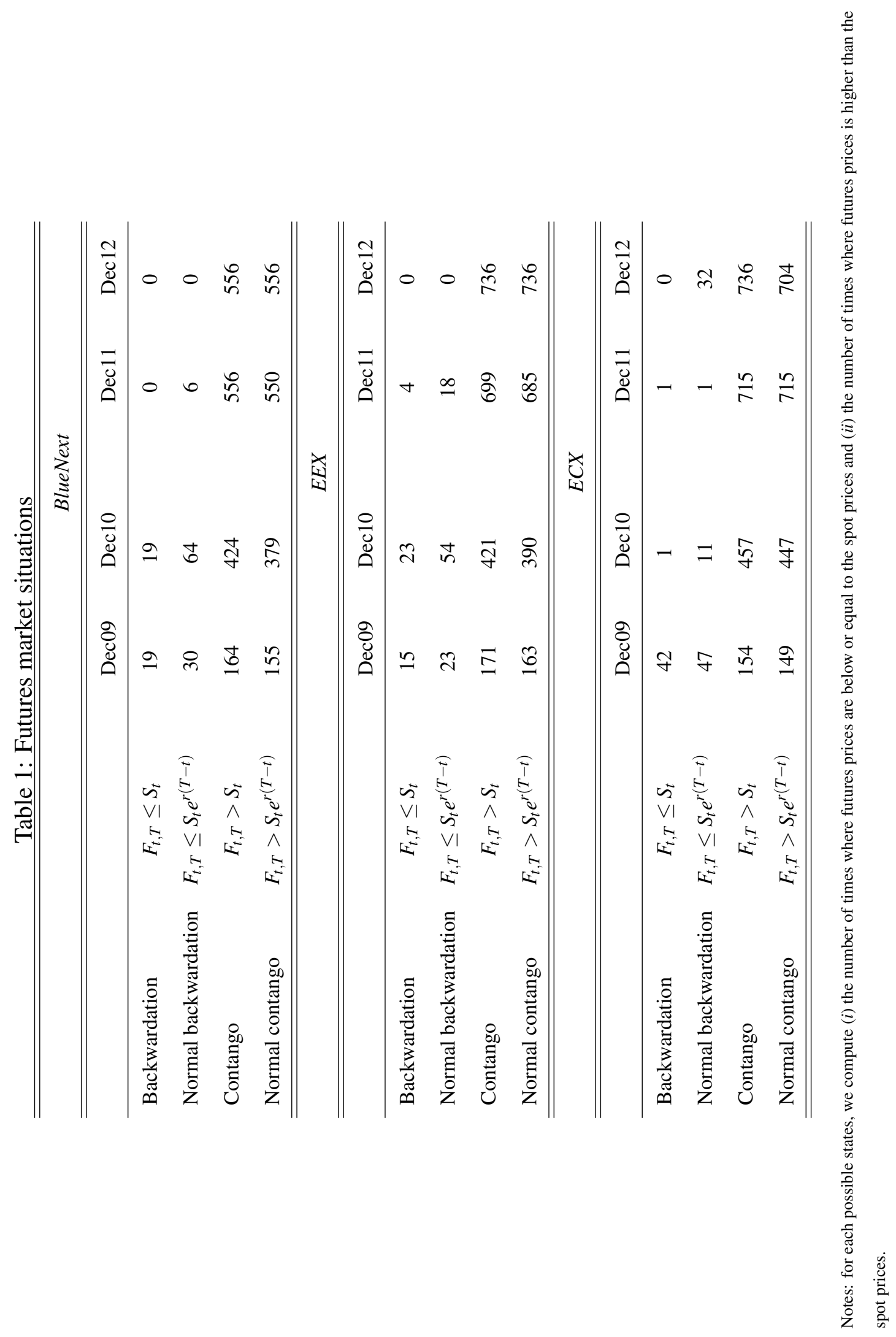


Daskalakis et al. (2009) developed an empirically and theoretically valid framework for the pricing and hedging of intra-phase and inter-phase futures and options on futures, respectively, on ECX and Nordpool. In the case of EUA futures, only intra-phase contracts (December 2006 and December 2007) are found to be well described by the cost-of-carry model with zero convenience yields. For interphase futures (December 2008 and December 2009), although the cost-of-carry model is still applicable, a stochastic, mean reverting convenience yield is needed for accurate pricing. Uhrig-Homburg and Wagner (2009) use a cost-of-carry model with implied yields for spot prices on Bluenext, and December 2006, December 2007 and December 2008 futures prices on ECX. They find obvious arbitrage possibilities in the market during the year 2005. Empirical evidence suggests that after December 2005, spot and futures prices are linked by the cost-of-carry approach within the first trading period. Temporary deviations from this linkage may exist but generally vanish after only a few days. Moreover, these authors show that the $\mathrm{CO}_{2}$ futures market leads the price discovery process. Joyeux and Milunovich (2010) investigate the relationship between spot prices on Bluenext, and December 2006 and December 2007 futures prices on ECX during Phase I over the period of June 2005 to December 2007. They reject the cost-of-carry hypothesis (without costs of storage and without convenience yield) for the entire period but find some evidence of improvement in market efficiency over the period using recursive estimates of the cost-of-carry parameters.

\section{Econometric methodology}

As the test of cost-of-carry model involves estimation of the cointegrating regression (i.e. a long-term relationship between the series), it is first relevant to test for cointegration between the series (futures prices, spot prices and interest rate) before estimating the cost-of-carry relationship. 


\subsection{Cointegration tests}

In order to conduct cointegration tests, we first estimate a vector-autoregressive (VAR) model on log series. The $\operatorname{VAR}(p)$ model is defined as

$$
Y_{t}=A_{1} Y_{t-1}+\cdots+A_{p} Y_{t-p}+\varepsilon_{t}
$$

where $Y_{t}$ is a vector of non-stationary variables, $\varepsilon_{t}$ is innovation vector. The lag length, noted $p$, of the $\operatorname{VAR}(p)$ is determined from the criteria discussed in Lütkepohl (1991) to determine the lag length ${ }^{10}$ Then, we implement the Johansen maximum likelihood procedure (Johansen, 1988, 1991). This approach consists in estimating a Vector Error Correction Model (VECM) by maximum likelihood, under various assumptions about the trend or intercept parameters and the number $r$ of cointegrating vectors, then conducting likelihood ratio tests. We re-write a $p$-dimensional VECM as follows

$$
\Delta Y_{t}=\sum_{i=1}^{p-1} \Gamma_{i} \Delta Y_{t-i}+\Pi Y_{t-1}+\varepsilon_{t}
$$

where $\Delta$ is a difference operator, $\Pi=\sum_{i=1}^{p} A_{i}-I m$, the matrices $\Gamma_{i}=-\sum_{j=i+1}^{p} A_{j}$ contain information on the short-run adjustment coefficients of the lagged differenced variables, the expression $\Pi Y_{t-1}$ indicates the error correction term, i.e. it includes the long-run relationships between the time series.

Johansen (1995) considers five restrictions on the deterministic components. In model 1 the level data $Y_{t}$ have no deterministic trends and the cointegrating equations do not have intercepts, giving the most restrictive specification. In model 2 the level data $Y_{t}$ have no deterministic trends and the cointegrating equations have intercepts. In model 3 the level data $Y_{t}$ have linear trends but the cointegrating equations have only intercepts. In model 4 the level data $Y_{t}$ and the cointegrating equations have linear trends. In model 5 the level data $Y_{t}$ have quadratic trends and the cointegrating equations have linear trends, giving the least restrictive specification. These five cases are nested from

\footnotetext{
${ }^{10}$ Results are not given to save space but they are available from the authors upon request.
} 
the most restrictive (model 1) to the least restrictive (model 5).

Since it is rare that the deterministic specification is well known a priori, Johansen (1995) suggests a procedure to determine jointly the co-integration rank and the deterministic components of the model. The procedure is based on the so-called Pantula (1989) principle: ${ }^{11}$ Start from the most restrictive model and then compare the rank test statistic with the chosen quantile of the corresponding table. If the model is rejected, continue to the model that restricts the constant to the cointegration space. If this model is also rejected, go to the model with an unrestricted constant. In the case of rejection, proceed to the model with linear trends in the variables and the cointegration space. If this is also rejected, repeat the procedure for the next rank. Continue until the null hypothesis cannot be rejected for the first time.

Johansen $(1988,1991)$ proposes to use the trace test ${ }^{12}$ which is based on the loglikelihood ratio

$$
\operatorname{LR}(r \mid k)=-T \sum_{i=r+1}^{k} \ln \left(1-\lambda_{i}\right)
$$

where $\lambda_{i}$ is the eigenvalue ranked at the $i$ order, $k$ is the number of endogenous variables, and $r=k-1, \ldots, 1,0$. This LR statistic tests the null hypothesis of $r$ cointegrating relations against the alternative of $k$ cointegrating relations, where $k$ is the number of endogenous variables, for $r=0,1, \ldots, k-1$.

\footnotetext{
${ }^{11}$ We suggest the use of the Pantula (1989) principle as a simple and practical way to simultaneously determine the co-integration rank and the deterministic components of a co-integration model.

${ }^{12}$ Based on simulation experiences, Lutkepohl et al. (2001) show that the trace test display better properties that the maximum eigenvalue test.
} 


\subsection{Cointegration tests with structural breaks}

One way for testing the multivariate cointegration in the presence of structural breaks is the approach developed by Johansen et al. (2000) which generalized the Johansen (1988) maximum likelihood cointegration test in order to include up to two known breaks. These authors extend the standard VECM with a number of additional variables in order to account for $q$ exogenous breaks in the levels and trends of the deterministic components of a vector-valued stochastic process. Specifically, Johansen et al. (2000) describe the model as follows

$$
\Delta Y_{t}=\alpha\left(\begin{array}{c}
\beta \\
\gamma
\end{array}\right)^{\prime}+\left(\begin{array}{c}
Y_{t-1} \\
t E_{t}
\end{array}\right)+\mu E_{t}+\sum_{i=1}^{p-1} \Gamma_{i} \Delta Y_{t-i}+\sum_{i=1}^{p} \sum_{v=1}^{q} \kappa_{v, i} D_{v, t-i}+\varepsilon_{t}
$$

where $Y_{t}$ is a vector of non-stationary variables, $\Delta$ is a difference operator, $t=1, \ldots, T$ represents the number of sample periods being $q$ with, as an example, a length $T_{v}-T_{v-1} ; \mu=\left(\mu_{1} \ldots \mu_{q}\right) ; \gamma=\left(\gamma_{1}^{\prime} \ldots \gamma_{q}^{\prime}\right)^{\prime} ; D_{v, t}$ equals 1 for $t=T_{v-1}$ and 0 otherwise; $E_{t}=\left(E_{1 t} \ldots E_{q t}\right)^{\prime}$ for $E_{v t}=\sum_{i=p+1}^{T_{v}-T_{v-1}} D_{v, t-1}$ which is equal to 1 for $T_{v-1}+p+1 \leqslant t \leqslant T_{v}$ and 0 otherwise. $D_{v, t-1}$ can be considered as an indicator function for the $i$ th observation in the vth period while $E_{\mathrm{v} t}$ covers the sample for the vth period.

\section{Empirical results}

The study sample consists of the daily closing prices of spot EUA prices and futures EUA prices of maturity December 2009, December 2010, December 2011 and December 2012, covering the period March 13, 2009 to January 17, 2012, both prices negotiated on BlueNext, ECX and EEX. ${ }^{13}$ The data on Euribor zero curve swap interest rates are obtained from Thomson Financial Datastream. In order to match the interest

\footnotetext{
${ }^{13}$ Data are available on www.bluenext.fr, www.eex.com and www.theice.com.
} 
rate maturity to the maturity of the futures contracts effectively, that is, track the futures contracts through time, we interpolate the interest rates to monthly maturities within the data sample. The formula used is the Taylor Young formula at the first order for an $x$ horizon time, $t<x<t+1$, and $r_{x}$ the corresponding interest rate

$$
r_{x}=r_{t+1}+(x-t)\left(r_{t+1}-r_{t}\right) /(t+1-t)
$$

Table 2 presents summary statistics for the returns calculated as the first differences in the logs of the EUA spot prices, futures prices and interest rate, for the three markets. All the returns are highly non-normal, i.e. showing evidence of significant negative skewness and excess kurtosis, as might be expected from daily log-returns, except for the spot and futures log-returns relative to the December 2009 maturity. The kurtosis coefficient is significant, implying that the distribution of the log-returns is leptokurtic (i.e., fat-tailed distribution) and thus the variance of the $\mathrm{CO}_{2}$ prices is principally due to infrequent but extreme deviations. The skewness coefficient is negative and significant for the spot and futures log-returns, implying that there is more negative log-returns than positive log-returns. This result means that the distribution of the spot and futures price changes is asymmetric. The Lagrange Multiplier test for the presence of the ARCH effect clearly indicates that the log-returns show strong conditional heteroscedasticity, which is a common feature of financial data. In other words, there are quiet periods with small price changes and turbulent periods with large oscillations.

Prior to testing for cointegration, non-stationarity must be established. We apply various unit root tests with and without structural breaks on all the series and find that all of them are characterized by a unit root. When tests are applied on series in firstdifference, they are found to be stationary. ${ }^{14}$ In other words, all series are integrated

\footnotetext{
${ }^{14}$ All results are available upon request to the authors.
} 
Table 2: Statistical analysis of log-returns series

\begin{tabular}{|c|c|c|c|c|c|c|}
\hline Data & Obs. & Mean $(\%)$ & SD & Skewness & Kurtosis & $\mathrm{ARCH}(10)$ \\
\hline \multicolumn{7}{|l|}{ Bluenext } \\
\hline Spot09 data & 184 & 0.0583 & 0.0245 & $-0.2165^{*}$ & 3.0680 & $18.99^{*}$ \\
\hline Dec09 Futures data & 184 & 0.0347 & 0.0237 & $-0.1596^{*}$ & 2.9140 & $23.60^{*}$ \\
\hline Interest rate (matching Dec09) & 184 & -1.1873 & 0.01884 & $-0.6548^{*}$ & $7.9922^{*}$ & $95.15^{*}$ \\
\hline Spot10 data & 442 & 0.0526 & 0.0210 & $-0.3201^{*}$ & $3.8876^{*}$ & $39.75^{*}$ \\
\hline Dec10 Futures data & 442 & 0.0330 & 0.0203 & $-0.3123^{*}$ & $4.1396^{*}$ & $36.52^{*}$ \\
\hline Interest rate (matching Dec10) & 442 & -0.8847 & 0.0209 & -0.1956 & $7.3153^{*}$ & $50.52^{*}$ \\
\hline Spot11 data & 555 & 0.0628 & 0.0196 & $-0.2694^{*}$ & $4.4260^{*}$ & $56.58^{*}$ \\
\hline Dec11 Futures data & 555 & 0.0385 & 0.0186 & $-0.2953^{*}$ & $4.6521^{*}$ & $52.81^{*}$ \\
\hline Interest rate (matching Dec11) & 555 & -0.3077 & 0.0191 & $0.4021^{*}$ & $4.5059^{*}$ & $20.65^{*}$ \\
\hline Spot12 data & 555 & 0.0628 & 0.0196 & $-0.2694^{*}$ & $4.4260^{*}$ & $56.58^{*}$ \\
\hline Dec12 Futures data & 555 & 0.0331 & 0.0182 & $-0.3066^{* *}$ & $4.7308^{*}$ & $49.03^{*}$ \\
\hline Interest rate (matching Dec12) & 555 & -0.3077 & 0.0191 & $0.4022^{*}$ & $4.5059^{*}$ & $20.65^{*}$ \\
\hline \multicolumn{7}{|l|}{$E E X$} \\
\hline Spot09 data & 185 & 0.0536 & 0.0239 & $-0.2456^{*}$ & 3.1821 & $27.14^{*}$ \\
\hline Dec09 Futures data & 185 & 0.0367 & 0.0233 & $-0.1798^{*}$ & 3.0061 & $21.82^{*}$ \\
\hline Interest rate (matching Dec09) & 185 & -1.9061 & 0.0337 & $-2.6590^{*}$ & $13.8539^{*}$ & $114.80^{*}$ \\
\hline Spot10 data & 443 & 0.0471 & 0.0202 & $-0.3899^{*}$ & $4.4963^{*}$ & $45.00^{*}$ \\
\hline Dec10 Futures data & 443 & 0.0314 & 0.0200 & $-0.3620^{*}$ & $4.1987^{*}$ & $30.47^{*}$ \\
\hline Interest rate (matching Dec10) & 443 & -0.8805 & 0.0239 & $-0.8368^{*}$ & $7.3997^{*}$ & $113.72^{*}$ \\
\hline Spot11 data & 702 & -0.0512 & 0.0201 & $-0.3443^{*}$ & $4.8755^{*}$ & $55.79^{*}$ \\
\hline Dec11 Futures data & 702 & -0.0716 & 0.0204 & $-0.4661^{*}$ & $4.9856^{*}$ & $77.60^{*}$ \\
\hline Interest rate (matching Dec11) & 702 & -0.5817 & 0.0195 & 0.0209 & $5.7731^{*}$ & $96.62^{*}$ \\
\hline Spot12 data & 735 & -0.0829 & 0.0231 & $0.3547^{* *}$ & $9.9074^{*}$ & $62.47^{*}$ \\
\hline Dec12 Futures data & 735 & -0.1084 & 0.0225 & $0.2245^{*}$ & $10.3895^{*}$ & $62.10^{*}$ \\
\hline Interest rate (matching Dec12) & 735 & -0.2775 & 0.0206 & -0.0470 & $4.7737^{*}$ & $49.15^{*}$ \\
\hline \multicolumn{7}{|l|}{$E C X$} \\
\hline Spot09 data & 195 & 0.0903 & 0.0242 & $-0.1812^{*}$ & 3.1521 & 15.16 \\
\hline Dec09 Futures data & 195 & 0.0802 & 0.0241 & $-0.1637^{*}$ & 2.9240 & 13.28 \\
\hline Interest rate (matching Dec09) & 195 & -2.1639 & 0.0472 & $-4.5357^{*}$ & $31.0675^{*}$ & $124.59^{*}$ \\
\hline Spot10 data & 457 & 0.0313 & 0.0209 & $-0.2723^{*}$ & $4.0796^{*}$ & $39.86^{* *}$ \\
\hline Dec10 Futures data & 457 & 0.0148 & 0.0208 & $-0.2329^{*}$ & $3.8193^{*}$ & $38.41^{*}$ \\
\hline Interest rate (matching Dec10) & 457 & -1.1079 & 0.0261 & -2.4570 & 22.8679 & $310.78^{*}$ \\
\hline Spot11 data & 715 & -0.0764 & 0.0223 & $-0.4494^{*}$ & $4.7731^{*}$ & $90.89^{*}$ \\
\hline Dec11 Futures data & 715 & -0.0963 & 0.0219 & $-0.4567^{*}$ & $4.6820^{*}$ & $96.50^{*}$ \\
\hline Interest rate (matching Dec11) & 715 & -0.7444 & 0.0243 & $-2.6032^{*}$ & $-2.6032^{*}$ & $567.70^{*}$ \\
\hline Spot12 data & 735 & -0.0848 & 0.0241 & $0.2777^{*}$ & $10.5063^{*}$ & $70.04^{*}$ \\
\hline Dec12 Futures data & 735 & -0.1095 & 0.0233 & $0.2155^{*}$ & $10.2357^{*}$ & $76.14^{*}$ \\
\hline Interest rate (matching Dec12) & 735 & -0.2775 & 0.0206 & -0.0377 & $4.7582^{*}$ & $49.22^{*}$ \\
\hline
\end{tabular}

Notes: The skewness and kurtosis statistics are standard-normally distributed under the null of normality distributed returns.

$\mathrm{ARCH}(10)$ indicates the Lagrange multiplier test for conditional heteroscedasticity with 10 lags. ${ }^{*}$ means significant at the 5\% level. 
of order 1.

To identify the (possible) presence of structural breaks in the spot and futures EUA prices, we use the approach of Bai and Perron (2003). Two breaks are identified in December 21, 2009, and in June 24, 2011. The first break can be explained by the correlation between the natural gas and carbon markets. Since October 2009, the relationship between natural gas, coal and carbon prices seems to have returned. With prices of coal rising (by $4 \%$ in December) more than those of natural gas, the $\mathrm{CO}_{2}$ switch price dipped further below $\mathrm{CO}_{2}$ market price, providing an incentive for power producers to switch from coal to gas. Lower demand for $\mathrm{CO}_{2}$ allowance resulting from this switch (burning gas emits half as much carbon as burning coal) might have contributed to lower carbon prices. The second break is due to the reaction to the announcement of a Directive of the European Commission involving a $20 \%$ drop in prices. The European $\mathrm{CO}_{2}$ allowance prices fell sharply (-20\%) between June 24 and June 26, 2011, before stabilizing between $€ 13$ and $€ 14$ per tonne, compared with a business-as-usual price of $€ 25$. The EU's upcoming "energy efficiency directive," presented the 22th of June 2011, propose a new contract with member states for cutting energy consumption in buildings, vehicles and more controversially, industry. This overlying mandate for energy efficiency put a further layer of regulation on top of the EU's main tool for reducing greenhouse gas emissions. This will reduce demand for permits - by about 400 million tonnes in 2013-2020, EU sources say - leaving them in the market and applying downward pressure on prices.

To test between the models used in Johansen (1995) and Johansen et al. (2000), the Pantula principle is used to test the joint hypothesis of both rank and the components 15 The test procedure moves from the most restrictive model to the least restrictive model

\footnotetext{
${ }^{15}$ For the Johansen test, we consider the five specifications. For the Johansen et al. test, we only consider the models 2 and 3 .
} 
comparing the trace statistic at each stage to its critical value and stopping when the null is not rejected. 16

Results of the cointegration tests are given in Table $3^{17}$ The null hypothesis of none cointegrating vector is rejected, and there is one cointegrating vector at the $5 \%$ significance level from the cointegration tests with and without structural breaks. Therefore, futures contracts, whatever the maturity, are cointegrated with spot prices and interest rates for the three $\mathrm{CO}_{2}$ markets.

As the series are $I(1)$ and cointegrated, we may estimate Equation (4) to test the efficiency hypothesis. Results are presented in Table 4. The cost-of-carry relationship between the futures and spot prices further implies that since price movements in both prices are subject to common information set(s), therefore, law of one price must hold (Hasbrouck, 1995) and any deviation between two price series must be subject to transaction cost (Protopapadakis and Stoll, 1983). Firstly, we can see that the coefficient $\alpha$ on the $\mathrm{CO}_{2}$ spot price variable is strongly different to its theoretical value of one in futures price equations, whatever the maturity and the $\mathrm{CO}_{2}$ market. Similarly, we reject the null that the coefficient $\beta$ on the interest rate variable is equal to one. Thus, according to the individual tests, the cost-of-carry model is rejected for all maturities and $\mathrm{CO}_{2}$ markets. Secondly, these findings are confirmed by the rejection of the joint hypothesis on $\alpha$ and $\beta$, implying significant violations of law of one price, and that neither contract is priced according to the cost-of-carry model. Indeed, even if stable long-run relationship is observed between the futures and spot prices, during short-run, both price series significantly deviate from each other and offer exploitable arbitrage opportunities (Cox et al., 1981). In the presence of market frictions, such as transaction costs and order execution lags, the no-arbitrage condition should hold in the long run but not necessarily in the short term (Joyeux and Milunovich, 2010).

\footnotetext{
${ }^{16}$ Results are not given to save space but they are available from the authors upon request.

${ }^{17}$ We have specified the order lags of the VAR models from the criteria discussed in Lükepohl (1991).
} 
Table 3: Cointegration tests for BlueNext, EEX and ECX

\begin{tabular}{|c|c|c|c|c|c|c|c|c|}
\hline & \multicolumn{2}{|c|}{ Dec09 } & \multicolumn{2}{|c|}{$\operatorname{Dec} 10$} & \multicolumn{2}{|c|}{ Dec11 } & \multicolumn{2}{|c|}{ Dec12 } \\
\hline & t-stat & $\mathrm{p}$-value & t-stat & $\mathrm{p}$-value & t-stat & p-value & t-stat & $\mathrm{p}$-value \\
\hline \multicolumn{9}{|c|}{ Johansen (1995) test } \\
\hline \multicolumn{9}{|c|}{ Bluenext } \\
\hline$r \leq 0$ & $76.75^{*}$ & 0.00 & $63.50^{*}$ & 0.00 & $60.01^{*}$ & 0.00 & $56.57^{*}$ & 0.00 \\
\hline$r \leq 1$ & 25.13 & 0.06 & 21.67 & 0.15 & 21.43 & 0.16 & 18.58 & 0.31 \\
\hline$r \leq 2$ & 9.60 & 0.15 & 8.12 & 0.25 & 7.31 & 0.32 & 4.64 & 0.65 \\
\hline \multicolumn{9}{|l|}{ EEX } \\
\hline$r \leq 0$ & $77.85^{*}$ & 0.00 & $77.17^{*}$ & 0.00 & $69.84^{*}$ & 0.00 & $57.81^{*}$ & 0.00 \\
\hline$r \leq 1$ & 25.19 & 0.06 & 21.41 & 0.16 & 19.21 & 0.07 & 15.75 & 0.19 \\
\hline$r \leq 2$ & 9.28 & 0.17 & 7.94 & 0.26 & 3.05 & 0.58 & 2.81 & 0.62 \\
\hline \multicolumn{9}{|l|}{$E C X$} \\
\hline$r \leq 0$ & $40.62^{*}$ & 0.04 & $42.03^{*}$ & 0.04 & $49.08^{*}$ & 0.01 & $54.69^{*}$ & 0.00 \\
\hline$r \leq 1$ & 17.19 & 0.41 & 23.48 & 0.10 & 18.72 & 0.30 & 17.15 & 0.13 \\
\hline$r \leq 2$ & 6.66 & 0.39 & 9.45 & 0.16 & 5.69 & 0.51 & 3.08 & 0.57 \\
\hline \multicolumn{9}{|c|}{ Johansen et al. (2000) test } \\
\hline \multicolumn{9}{|c|}{ Bluenext } \\
\hline$r \leq 0$ & - & - & $79.72^{*}$ & 0.00 & $71.92^{*}$ & 0.00 & $70.97^{*}$ & 0.00 \\
\hline$r \leq 1$ & - & - & 22.75 & 0.21 & 27.22 & 0.07 & 24.14 & 0.16 \\
\hline$r \leq 2$ & - & - & 8.68 & 0.30 & 11.66 & 0.12 & 8.64 & 0.32 \\
\hline \multicolumn{9}{|l|}{ EEX } \\
\hline$r \leq 0$ & - & - & $94.89^{*}$ & 0.00 & $89.20^{*}$ & 0.00 & $82.72^{*}$ & 0.00 \\
\hline$r \leq 1$ & - & - & 22.69 & 0.21 & 30.43 & 0.06 & 27.19 & 0.14 \\
\hline$r \leq 2$ & - & - & 8.41 & 0.32 & 11.10 & 0.22 & 9.39 & 0.37 \\
\hline \multicolumn{9}{|l|}{$E C X$} \\
\hline$r \leq 0$ & - & - & $75.01^{*}$ & 0.01 & $61.64^{*}$ & 0.03 & $60.41^{*}$ & 0.03 \\
\hline$r \leq 1$ & - & - & 5.45 & 0.83 & 30.68 & 0.20 & 22.39 & 0.65 \\
\hline$r \leq 2$ & - & - & 0.04 & 0.99 & 8.68 & 0.66 & 7.54 & 0.77 \\
\hline
\end{tabular}

* means significant at the $5 \%$ level. 
Table 4: The cointegrating vectors

\begin{tabular}{|c|c|c|c|c|}
\hline Hypotheses & Dec09 & Dec10 & Dec11 & Dec12 \\
\hline \multicolumn{5}{|l|}{ Bluenext } \\
\hline$\alpha=1$ & $-0.001^{*}$ & $\begin{array}{c}-0.003^{*} \\
(0.00)\end{array}$ & $\underset{(0.00)}{0.105^{*}}$ & $\frac{0.008^{*}}{(0.00)}$ \\
\hline$\beta=1$ & $\begin{array}{c}2.028^{*} \\
(0.00)\end{array}$ & $\begin{array}{c}1.561^{*} \\
(0.00)\end{array}$ & $\begin{array}{c}-0.939^{*} \\
(0.00)\end{array}$ & $\begin{array}{c}1.760^{*} \\
(0.00) \\
\end{array}$ \\
\hline$\alpha=\beta$ & $\begin{array}{l}-2.029^{*} \\
(0.00)\end{array}$ & $-{ }^{-1.564^{*}}$ & $\begin{array}{c}1.044^{*} \\
(0.00)\end{array}$ & $-{ }_{(0.00)}^{1.752^{*}}$ \\
\hline \multicolumn{5}{|l|}{$E E X$} \\
\hline$\alpha=1$ & $-{ }^{-0.001^{*}}$ & $\begin{array}{c}-0.002^{*} \\
(0.00)\end{array}$ & $\begin{array}{c}-0.001^{*} \\
(0.00)\end{array}$ & $\frac{0.002^{*}}{(0.00)}$ \\
\hline$\beta=1$ & $\begin{array}{l}-2.019^{*} \\
(0.00)\end{array}$ & $\begin{array}{c}1.544^{*} \\
(0.00)\end{array}$ & $\begin{array}{c}0.981^{*} \\
(0.00)\end{array}$ & $\underset{(0.00)}{0.807^{*}}$ \\
\hline$\alpha=\beta$ & $\begin{array}{c}-2.018^{*} \\
(0.00) \\
\end{array}$ & $\begin{array}{c}-1.546^{*} \\
(0.00) \\
\end{array}$ & $\begin{array}{c}-0.982^{*} \\
(0.00) \\
\end{array}$ & $\begin{array}{c}-0.805^{*} \\
(0.00) \\
\end{array}$ \\
\hline \multicolumn{5}{|l|}{$E C X$} \\
\hline$\alpha=1$ & $-{ }_{(0.00)}^{0.0011^{*}}$ & $\begin{array}{c}-0.0022^{*} \\
(0.00)\end{array}$ & $-\frac{0.0024^{*}}{(0.00)}$ & $\frac{0.0005^{*}}{(0.00)}$ \\
\hline$\beta=1$ & ${ }^{1.8117^{*}}$ & $\begin{array}{c}1.4497^{*} \\
(0.00)\end{array}$ & $\begin{array}{c}1.0386^{*} \\
(0.00)\end{array}$ & $\begin{array}{c}0.8474^{*} \\
(0.00)\end{array}$ \\
\hline$\alpha=\beta$ & $-{ }_{(0.00)}^{1.8128^{*}}$ & $\begin{array}{c}-1.4519^{*} \\
(0.00)\end{array}$ & $\begin{array}{c}-1.0410^{*} \\
(0.00)\end{array}$ & $\begin{array}{c}-0.8469 \\
(0.00)\end{array}$ \\
\hline
\end{tabular}

Notes: The individual hypothesis are $H_{0}: \alpha=1$ and $H_{0}: \beta=1$. The joint hypothesis is $\alpha=\beta=1$. ${ }^{*}$ means significant at the $5 \%$ level. The $p$-value are given in brackets. 


\section{Discussion and Conclusion}

Understanding the relationship between spot and futures prices is thus of crucial importance for all participants in the carbon market. Carbon trading works only if markets for carbon provide enough liquidity and pricing accuracy, i.e., markets provide

prices that are useful for hedgers and other users of carbon markets. The efficiency of the $\mathrm{CO}_{2}$ market is particularly important for emission intensive firms, policy makers, risk managers and for investors in the emerging class of energy and carbon hedge funds.

Newberry (1992) suggests that futures markets provide opportunities for market manipulation. According to this view, the futures market can be manipulated either by the better informed at the expense of the less informed or by the larger at the expense of the smaller (Maslyuk and Smyth, 2009). If carbon markets are inefficient the policy implications are that there is a greater role for regulation to improve information flows and reduce market manipulation (Stout, 1995). It is imperative that policy makers address these issues during the eminent reviewing process, to ensure that the EU ETS evolves into a mature, efficient and internationally competitive market.

Recently, Krishnamurti and Hoque (2011) suggest four propositions to improve the efficiency of the $\mathrm{CO}_{2}$ markets: (i) emission permits should not be freely allocated; (ii) intertemporal use of permits should be allowed; (iii) international linkage and trading of permits must be fully explored; and (iv) an independent administrator must be set up to administer all issues pertaining to emissions allocation and trading.

We modeled the relationship between futures and spot prices in the European carbon markets from the cost-of-carry hypothesis to investigate the extent of efficiency market. We studied the three main European markets (BlueNext, EEX and ECX), and four futures contracts (December 2009, December 2010, December 2011, and December 2012) during Phase II, covering the period from March 13, 2009 to January, 17, 2012. 
We found that futures contracts, whatever the maturity, were cointegrated with spot prices and interest rates for the three $\mathrm{CO} 2_{2}$ markets from cointegration tests with and without structural breaks. According to individual and joint tests, the cost-ofcarry model was rejected for all maturities and $\mathrm{CO}_{2}$ markets, implying that neither contract was priced according to the cost-of-carry model. The absence of the costof-carry relationship can be interpreted as an indicator of market inefficiency and may bring arbitrage opportunities in the $\mathrm{CO}_{2}$ market. If the cost of carry model is not observed, arbitrage opportunities can happened. An investor can benefit from an arbitrage opportunity when the cost of buying the right of carbon emission, is lower than the price at which the said emission can be sold in the future, and where such sale price can be locked-in by the investor by means of selling a futures contract. On the specified date in the futures contract, the investor will deliver the physical or financial asset and crystallize the arbitrage profit. Thanks to arbitrage, all prices for a given asset are equal at a given point in time. Arbitrage ensures fluidity between markets and contributes to their liquidity. It is the basic behavior that guarantees the efficient market (Vernimmen, 2011). 


\section{References}

[1] Alberola, E., Chevallier, J., Chï£jze, B. (2008). Price drivers and structural breaks in European carbon prices 2005-2007. Energy Policy, 36, 787-797.

[2] Bai, J., Perron, P. (2003). Computation and analysis of multiple structural change models. Journal of Applied Econometrics, 18, 1-22.

[3] Benz, E., Trück, S. (2009). Modeling the price dynamics of $\mathrm{CO}_{2}$ emission allowances. Energy Economic, 31, 4-15.

[4] Borak, S., Härdle, W., Trück, S., Weron, R. (2006). Convenience yields for $\mathrm{CO}_{2}$ emission allowance futures contracts. SFB 649 Discussion Paper No 2006-076, Humboldt University.

[5] Chevallier, J. (2012). Banking and borrowing in the EU ETS: A review of economic modelling, current provisions and prospects for future design. Journal of Economic Surveys, 26, 157-176.

[6] Convery, F.J. (2009). Origins and development of the EU ETS. Environmental and Resource Economics, 43, 391-412.

[7] Cox, J.C., Ingersoll, J.E., Ross, S.A. (1981). The relation between forward prices and futures prices. Journal of Financial Economics, 9, 321-346.

[8] Daskalakis, G., Markellos, R.N. (2008). Are the European carbon markets efficient? Review of Futures Markets, 17, 103-128.

[9] Daskalakis G., Psychoyios, D., Markellos, R.N. (2009). Modeling $\mathrm{CO}_{2}$ emission allowance prices and derivative: Evidence from the European trading scheme. Journal of Banking and Finance, 33, 1230-1240. 
[10] Gregory, A.W., Nason, J.M., Watt, D.G. (1996). Testing for structural breaks in cointegrated relationships. Journal of Econometrics, 71, 321-341.

[11] Hasbrouck, J. (1995). One security, many markets: Determining the contributions to price discovery. Journal of Finance, 50, 1175-1199.

[12] Hicks, J. (1946). Value and Capital, 2nd Edition. London: Oxford University Press.

[13] Johansen, S. (1988). Statistical analysis of cointegration vectors. Journal of Economic Dynamics and Control, 12, 231-54.

[14] Johansen, S. (1991). Estimation and hypothesis testing of cointegration vectors in Gaussian vector autoregressive models. Econometrica, 59, 1551-1580.

[15] Johansen, S. (1995). Likelihood-based Inference in Cointegrated Vector Autoregressive Models. Oxford University Press, Oxford.

[16] Johansen, S., Mosconi, R., Nielsen, B. (2000). Cointegration analysis in the presence of structural breaks in the deterministic trend. Econometrics Journal, 3, 216-249.

[17] Joyeux, R., Milunovich, G. (2010). Testing market efficiency in the EU carbon futures market. Applied Financial Economics, 20, 803-809.

[18] Kaldor, N. (1939). A note on the theory of the forward market, Review of Economic Studies, 8, 196-201.

[19] Keynes, J. (1930). A Treatise on Money, Vol 2. London: Macmillan.

[20] Krishnamurti, C., Hoque, A. (2011). Efficiency of European emissions markets: Lessons and implications. Energy Policy, 39, 6575-6582. 
[21] Levy, D., Bergen, M., Dutta, S., Venable, R. (1997). Magnitude of menu costs: Direct evidence from large U.S. supermarket chains. The Quarterly Journal of Economics, 112, 791-825.

[22] Lütkepohl, H. (1991). Introduction to Multiple Time Series. Springer-Verlag, New York.

[23] Lütkepohl, H., Saikkonen, P., Trenkler, C. (2001). Maximum eigenvalue versus trace test for the cointegrating rank of a VAR process. Econometrics Journal, 4, 287-310.

[24] Maslyuk, S., Smyth R. (2009). Cointegration between oil spot and future prices of the same and different grades in the presence of structural change. Energy Policy, 37, 1687-1693.

[25] Newberry, D.M. (1992). Futures markets: Hedging and speculation. In Newman, P., Milgate, M., Eatwell, J. (Eds.), The New Palgrave Dictionary of Money and Finance (vol.2), Macmillan, London.

[26] Pantula, S.G. (1989). Testing for unit roots in time series data. Econometric Theory, 5, 256-271.

[27] Paolella, M.S., Taschini, L. (2008). An econometric analysis of emission allowance prices. Journal of Banking and Finance, 32, 2022-2032.

[28] Protopapadakis, A., Stoll, H.R. (1983). Spot and futures prices and the law of one price. Journal of Finance, 38, 1431-1455.

[29] Stigler, M. (2010). Threshold cointegration: Overview and implementation in R. Working Paper.

[30] Stoll, H.R., Whaley, R.E. (1990). The dynamics of stock index and stock index futures returns. Journal of Financial Quantitative and Analysis, 25, 441-468. 
[31] Stout, L.A. (1995). Are stock markets costly casinos? Disagreement, market failure and securities regulation. Virginia Law Review, 81, 611-712.

[32] Uhrig-Homburg, M., Wagner, M. (2009). Futures price dynamics of $\mathrm{CO}_{2}$ emission certificates - An empirical analysis. The Journal of Derivatives, 17, 73-88.

[33] Vernimmen, P. (2011) Corporate Finance, Theory and Practice. John Wiley \& Sons; 3rd Edition, 1024 pages.

[34] Ward, R. (1982). Asymmetry in retail, wholesale and shipping point pricing for fresh vegetables. American Journal of Agricultural Economics, 64, 205-212. 